\title{
INTERNATIONAL PRUDENTIAL REGULATION, REGULATORY RISK AND COST OF BANK CAPITAL
}

\author{
Phong T. H. Ngo \\ Australian National University
}

\begin{abstract}
We define regulatory risk as regulation that leads to an increase in the cost of capital for a regulated firm. In a general equilibrium setting, scholars have shown that uniform increases in capital requirements lead to an increase in the cost of capital. We extend their model to show that when regulatory standards differ across countries, financial integration leads to positive spillovers that reduce the cost of capital mark up for a given increase in bank capital. Accordingly, regulatory risk may be greater under a regulatory agreement such as the Basel Accord, which imposes international uniformity in capital ratios.

JEL Classication: G15, G21 \& G28

Keywords: Basel Accord, bank capital regulation, cost of capital, regulatory risk, international harmonization.
\end{abstract}

\section{Introduction}

International finance has witnessed remarkable changes in the past two decades. The removal of restrictions on cross-border capital flows and the opening up of domestic markets to foreign competitors have seen an ever-growing internationalization of financial and banking activities. This is all good given the substantial literature documenting that well-functioning financial markets accelerate economic growth, which in turn, alleviates poverty. ${ }^{1}$ Nevertheless, looking at international financial markets over the past two decades, some have suggested that a potential cost of financial globalization may be the staggering scope of financial crises that have occurred in Argentina, Indonesia, Mexico, Russia, Thailand, and some South and East Asian economies, as the more prominent examples that come to mind. ${ }^{2}$

\footnotetext{
${ }^{1}$ See Levine (1997) for a discussion on finance and growth while Dollar and Kraay (2000) provide discussion on poverty and growth.
} 
The economic and social costs of such crises have been studied and are well documented. This has led to calls for reforming financial regulation. ${ }^{3}$ As such, there has been a wave of new regulations that have hit financial sectors across the globe in recent years. In some cases, regulatory demands have come not just from domestic regulators, but also from international initiatives such as the Basel Capital Accords and European Union (EU) directives.

The 1988 Basel Accord was a landmark regulatory agreement. For the first time, regulations affecting banks in many different countries were jointly established (Wagster, 1996) ${ }^{4}$ The ostensible goals of the Basel Accord were to minimize the systematic risk of the international banking system by limiting the competitive advantage that banks which had belonged to regulatory regimes with less stringent capital standards. This had the effect of leveling the playing field. ${ }^{5}$ Ultimately, the goal of the Accord was to remove the funding-cost advantage that Japanese banks had, which saw them capture over a third of international lending during the 1980's. In January 2001, the Basel Committee issued a proposal for a Basel II Capital Accord that, once finalized, would replace the 1988 Basel I Accord. It is now slated for implementation in 2007 by a number of countries. The proposal is based on three pillars. The first is improved minimum capital standards. The second focuses on better, supervisory practices. The third argues for greater market discipline through increased information disclosures by banks. With these, there has been an ever-growing perception of regulation as an additional risk, henceforth known as regulatory risk, which corporations must manage.

A recent article published by The Banker reporting the results of the 2003 survey conducted by the Centre for the Study of Financial Innovation claimed that there is a long term trend of regulation increasingly being viewed as a risk, not only by bankers, but also by non-bankers and analysts. One banker was quoted as saying that "banks will end up managing Basel II rather than managing risk," while one bank chairman told the magazine the following: "...political dogma, enforced by socialist governments in Europe and the U.K. is increasingly damaging the commercial viability of the banking industry. On the other hand, it is common place for the regulators, such as Bernie Egan of the Australian Prudential Regulation Authority, to remark the following: 'The net cost to shareholders would be quite modest. I would have thought a small price for shareholders to pay....".

Though this may sound like a contradiction in terms, regulation is supposed to minimize risk, not exacerbate it. The concerns of the regulated firms are real and should be examined more closely. In the taxation literature, there is a sound

\footnotetext{
${ }^{2}$ It should be noted that these crises were not born out of financial liberation per se, rather, they have more to do with these countries pursuing .xed exchange rate regimes and other interventionist policies such as the rescue of insolvent banks and poor prudential standards

${ }^{3}$ On the costs of recent crises see Boyd, Kwak, and Smith (2000) and Hoggarth, Resi, and Saporta (2001).
} 
body of evidence that has since the mid-1990s led to parliaments requiring estimates of compliance costs of all tax legislation, before a tax law is enacted. Nothing like that has been done for the Basel Accord cost. At the very least, one should ask whether all the costs of regulation have been taken into account when devising and implementing new policy. This paper adds to the debate by investigating a potential cost arising from regulatory risk of the international harmonization of financial regulation.

This paper defines regulatory risk as being any regulatory action that leads to an increase in the ex-ante cost of capital for the regulated. Thus, the paper examines the impact that the international capital adequacy requirements introduced by the Basel Accord may have on the cost of bank capital. The results indicate that uniform increases in capital requirements lead to an increase in the cost of capital. However, when regulatory standards differ across countries, financial integration leads to positive spillovers that reduce the cost of capital mark up for a given increase in bank capital. Accordingly, regulatory risk may be greater under a regulatory agreement such as Basel.

We also find that independent regulators will react to lax regulations of opposing countries by strengthening their own regulatory standards. This is an interesting result since the literature addressing the issue of regulatory competition concludes on the lines that when responding to lax financial regulations in another country, regulators will always choose to reduce regulatory requirements, leading to the so called "race to the bottom".

The next section provides a definition of regulatory risk and discusses the intuition behind and postulates the effects that capital regulation has on the cost of bank capital. A model is then proposed in Section 3, while Section 4 concludes this paper.

\section{Regulatory risk and the cost of capital}

There is much ambiguity surrounding the definition and sources of regulatory risk. To date, there does not appear to be a precise definition. The term regulatory

\footnotetext{
${ }^{4}$ The Basel Committee on Banking Supervision oversees the Basel Accord. The committee was formed in 1974 by the central bank governors of the G-10 countries, along with Switzerland and Luxembourg, in the aftermath of the failures of the Franklin National Bank in New York and Bankhaus Hersatt in Germany. The committee is under the auspices of the Bank for International Settlements and has no formal authority, thus its agreements are carried out on a voluntary basis by the member countries (Wagster, 1996).

${ }^{5}$ The term systematic risk belongs to the standard rhetoric of economic policy discussions relating to the finance industry. Despite the fact that systematic risk is one of the most popular buzzwords in the debate about banking regulation, it is fair to say that there is no precise definition (Summer, 2002). Prima facie, the literature shows that systematic risk is used as a description of many different phenomena. It is used to describe crises related to financial markets, to bank runs and bank panics, to contagion effects between financial markets.
} 
risk has been bantered around in policy discussions from just about every regulated industry one would care to think of. From the traditionally regulated, natural, industrial monopolies like telecommunications, water, electricity, gas, and railways, to regulations of environment, banking, finance, and pharmaceuticals, to more obscure regulations such as the alcohol content in the wine industry and the content and disclosure of information on websites.

The definitions of regulatory risk span from the risk of adverse government interventions to the risk of a regulatory breach, none of which provide a very useful framework for making predictions or providing us with testable implications. One would expect that, if regulation did indeed lead to greater risks, it would be reflected in the regulated entities' stock price or the cost of capital. Thus, the simplest and most useful definition is:

Regulatory risk arises whenever regulation affects (increases) the ex-ante cost of capital for a regulated firm, in this case a regulated bank.

The cost of capital is the rate of return that the suppliers of capital require from businesses in return for the provision of those funds. Any company that cannot achieve these returns will not be able to attract new funding. This required return is determined within the supply-demand equilibrium for funds in an economy. It will also vary between companies and projects according to their risk class, meaning that the higher the level of risk, the higher is the required rate of return. In other words, for a given risk of capital deployment in a firm or a project, the cost of capital can be thought of as the opportunity cost of funds invested in that business. Thus, an increase in the cost of capital is analogous to an increase in the risk of a firm or project.

When regulators impose higher capital requirements that are binding, capital deficient banks are forced to hold more capital. ${ }^{6}$ Consequently, their value will decline if their capital structure moves away from its optimal level and/or their ability to expropriate deposit-insurance subsidies from the insuring agency is reduced, leading to an increase in their cost of capital. Additionally, Gorton and Pennacchi (1990) argue that bank equity is uniquely costly, and that this cost comes from the role of demand deposits as an efficient means of exchange. The crucial point is, unlike deposits, bank equity is very sensitive to private information,

\footnotetext{
${ }^{6}$ Banks with capital holdings above the minimum requirement should not be affected as much as banks with capital holdings below the new requirement. Although banks currently hold capital well in excess of what is officially required by regulatory authorities, at the time of inception of the Basel Accord, almost all banks were capital deficient and were required to raise significant amounts of capital.

${ }^{7}$ General equilibrium in the Gorton and Winton (2000) sense where increases in capital requirements necessitates some agents in the economy to rebalance their portfolios by substituting one kind of bank liability for another. It should be noted that in this paper, the focus is on the cost of bank equity capital leaving aside considerations of the cost of debt capital. It is generally agreed upon that the determination of the cost of debt is relatively straightforward and is generally not a controversial issue (Grout, 1995). Furthermore, it is frequently established that the cost of equity exceeds that cost of debt and all of the complications related to the estimation of the cost of capital crop up with the measurement of the cost of equity capital owing to tax considerations, asymmetric information, agency costs, and moral hazard problems arising from deposit insurance.
} 
making it a bad medium for exchange. Thus, forcing banks to increase capital means that in general equilibrium, consumers must hold more bank equity (the less preferred medium of exchange) in aggregate, and therefore demand a higher expected return on equity in compensation, or put simply, a higher cost of capital. ${ }^{7}$

\section{The model}

The model proposed in this paper draws from the wisdom of several authors. In their seminal paper, Diamond and Dybvig (1983) advocated that banks provide liquidity by acting as risk-sharing arrangers to insure against depositors' random consumption needs. This model, the so-called "Diamond-Dybvig Model", can be likened with the idea that banks provide liquidity for consumers with uncertain consumption preferences. However, unlike Diamond and Dybvig (1983), where early liquidation of real assets causes an exogenous loss, the model presented here follows Gorton and Pennacchi (1990) where information asymmetries between investors lead to a wealth transfer from liquidity traders to strategic traders. ${ }^{1}$ Gorton and Pennacchi (1990) point out with reference to Jacklin (1987) and Cone (1983) that a pivotal assumption made by Diamond and Dybvig (1983) was that agents could not trade equity claims on physical assets. Contrary to this, it is the presence of informed traders that motivates the formation of an intermediary in their model.

They suggest that investors with uncertain consumption needs may be required to finance unexpected, high consumption by selling any securities they hold before their cash flows have been realized. To the extent that strategic trading can occur, the investor with such liquidity needs will be exposed to trading losses. However, if investors hold risk-free securities whose payoffs are fully known to all investors, they will not suffer trading losses to strategic traders. Consequently, there is a demand for low risk trading securities and banks meet this demand by issuing demand deposits. The important point to note from their paper is that

\footnotetext{
${ }^{8}$ In this framework, Gorton and Winton (2000) analyzed the impact of a system wide increase in capital requirements on the cost of bank equity. They used a general equilibrium setting where banks produce demand deposits by creating and holding loans. The model is general equilibrium in the sense that market clearing conditions require that bank capital increases are matched by decreases in total deposits as some agents in the economy rebalance their portfolios. Their work is unique in their emphasis on the role of bank deposits, which lead to a unique cost of bank equity capital in general equilibrium. Much of the earlier, theoretical work in bank capital was partial equilibrium and took the cost of bank equity capital as exogenous.

${ }^{9}$ This earlier work provided conflicting answers and tended to look at whether banks increased the risk of their asset portfolios when faced with an increase in the required capital ratio. The regulation of bank capital is often justified to attain a balance between the conflicting objectives of preventing costly bank runs with the moral hazard induced by the deposit insurance (Berger, Herring and Szego, 1995; Kaufman, 1991; Furlong Keeley, 1989; Keeley and Furlong, 1990). Nevertheless, whether the implementation of capital requirements actually reduces bank risk-taking incentives is still a moot point amongst researchers. As an example, authors such as Kahane (1977), Koehn and Santomero (1980), Lam and Chen (1985), Kim and Santomero (1988), Flannery (1989), Genotte and Pyle (1991), Rochet (1992), Besanko and Katanas (1996), and Blum (1999) argue that actual capital requirements can lead to an increase in bank risk taking behavior.
} 
relative to bank deposits, bank equity is very sensitive to private information, thus making it relatively costly, bad medium of exchange. The discipline of general equilibrium is essential for their results as it is for the results of this paper.

In general equilibrium, two aspects of banking create a tension in setting bank capital levels. On one hand, bank capital is (presumed) needed to prevent the social and private costs of bank failure. On the other hand, if capital requirements are binding, then some agents in the economy must be induced to hold bank equity, which means that they must be compensated for the additional costs associated with having to sell the equity when liquidity needs arise. If regulators increase system wide capital requirements (or as is the case with the Basel Accord, global increases in capital requirements in the aggregate), investors must hold more equity in their portfolios, increasing the chance that they must sell it to meet consumption needs, thus increasing the cost of capital.

In what follows, we model the relationship between private and social incentives to increase bank capital with the extent of regulatory forbearance, looking at the impact of a global increase in capital requirements on the cost of bank capital. The model is largely inspired by Gorton and Winton (2000). However, we extend their model by (i) looking more closely at how capture and competition in regulation influences regulatory forbearance, (ii) endogenizing regulatory forbearance into the choice of capital requirements, and (iii) incorporating multiple economies.

\subsection{Single economy model}

There are four dates in the model economy, $T=0 ; 1 ; 2 ; 3$, and a single consumption good. There is a single banking sector with a continuum of homogeneous banks, a continuum of risk neutral consumers, a bank regulator, and many competitive, risk neutral market makers. The following assumptions detail the model.

Consumer Preferences: All consumers are identical as of $T=0$. As in Diamond and Dybvig (1983), each faces a privately observed, uninsurable risk of being an 'early' consumer. That is, consumers either consume at date 2 or 3 , varying on how likely they are to consume early (i.e. suffer a liquidity shock). At $T=1$ consumers realize their probability of being an early consumer (i.e. consume at $T=2$ ), with say probability $t$. However, the shock itself does not occur until the beginning of $T=2$. There is continuum of risk neutral consumers with total mass of 1 who each have a unique type (probability) $t$, and the total distribution of types is uniform over $[0 ; 1]$. It follows that the total mass of consumers who suffer the liquidity shock and must consume early is precisely $t$. Given this framework and defining $C_{T}(t)$ as type $t$ consumption at time

$T$, a consumer of type $t$ has an expected utility at $\mathrm{T}=1$ of: 


\section{$B U(C 2,0) ;(t))=C_{1}(t)+(1-i) C_{3}(t)$}

Endowments and Initial Portfolios: At $T=0$, all agents receive endowments of one unit of a capital good which is invested to earn a return in the form of a consumption good at $T=3$. Additionally, at $T=2$, agents receive an extra endowment of $G$ units of the consumption good. The focus is on established banking systems that have outstanding loans and equity capital. Consequently, the representative bank has issued $D_{0}$ deposits promising to pay an exogenous interest factor $R_{D}$ at either $T=2$ or $T=3$ per unit of capital good invested and $N_{0}$ shares, with each shareholder holding $\mathrm{n}_{0}$ shares Since consumers are risk neutral, they will optimally choose portfolios that are either all deposits or all equity. We will see that selling equity at $T=2$ involves a discount, thus, consumers with the lowest probability of consuming early (lowest $t$ ) will hold portfolios consisting entirely of equity. As a result, there must exist a marginal shareholder of type $t^{*}$ who is indifferent between holding shares or deposits, such that all consumers with $t<t^{*}$ will hold equity so that in general equilibrium, $N_{0}=\mathrm{n}_{0} \mathrm{t}^{*}$. Market clearing implies that the remaining consumers hold deposits, that is $D_{0}=1-\mathrm{t}^{*}$.

Bank Technology: Capital is homogeneous, and each unit produces the same random return, $\tilde{r}$. It is assumed that $\tilde{r}$ is non-negative and belongs to a symmetric distribution with mean $R$, distribution $\mathrm{H}($.$) , and density \mathrm{h}($.$) , which implies that$ $\widetilde{r} \in[0,2 R]$. The assumption of symmetry is not essential. However, it does simplify later analysis. Let us specify an exogenous private bank charter value $C_{P}$. If the bank is solvent at $T=3$ then is $C_{P}$ preserved, and thus divided amongst the shareholders. Otherwise, the bank fails and $C_{P}$ is completely lost. Gorton and Winton (2000) point out that this private charter value is aimed at capturing the informational quasi-rents that banks are assumed to accrue in the lending process by having private information about their lending opportunities. This private information about borrowers is an intangible asset that has value contingent on the bank's continued operation. Moreover, the social cost of bank failure is generally regarded as being greater than the private costs. Generally speaking, the reason for this widely held belief stems from the so called 'contagion effect', or simply systematic risk, the notion that a bank failure could have knock on effects that cause difficulties for other financial institutions. Accordingly, we define the bank's social charter value as $C_{S} \geq C_{P}$. As with private charter value, this social charter value dissipates if the bank fails.

Regulator: There is a regulator in the economy, such as the Central Bank who designs regulatory mechanisms with the goal of maximizing aggregate social welfare. Deposits are insured, regulators levy lump sum taxes, $L$, to support deposit insurance and enforce capital standards to mitigate the moral hazard costs of insurance. Deposit insurance and capital requirements are both ex-ante mechanisms aimed at reducing the likelihood of bank failure. Later, we relax the 
assumption that the regulator's objective is to maximize social welfare and to include the possibility of capture or competition in regulation.

Market Makers: For simplicity it is assumed that there exist many competitive, risk neutral, market makers who compete for trades by offering bid and ask prices, $P_{B}$ and $P_{A}$, respectively. ${ }^{9}$ Bertrand competition ensures that competitive market makers earn zero economic rents so that each price fully reflects the expected value of the share, conditional on it being bought or sold. ${ }^{10}$

Timing: At $T=0$, banks exist with $D_{0}$ deposits offering a rate of $R_{\mathrm{D}}$ and $N_{0}$ shares of equity. At $T=1$, regulators announce new capital standards and banks raise more capital. The representative bank raises an amount of capital $K_{1=} N_{1} P_{1}$, where $N_{1}$ is the total number of new shares issued and $P_{1}$ is the issue price per share. Since existing shareholders hold portfolios made up entirely of equity, this new capital must come from existing depositors. Once again, consumers with the lowest probability of suffering a liquidity shock will find it optimal to hold this new equity. So as capital is raised, the marginal shareholder changes, precisely, there must be a new marginal shareholder $\mathbf{f}>$ who is indifferent between holding deposits or equity so that all consumers with $\mathbf{\times} \boldsymbol{\xi}$ strictly prefer holding only equity. Accordingly, ( $\hat{\boldsymbol{t}}-\mathbf{e} \boldsymbol{\mathbf { j }})$ depositors strictly prefer equity. If each depositor buys $n 1$ shares such that $\mathbf{m}_{\mathbf{1}} \boldsymbol{F}_{\mathbf{L}} \mathbf{- 1}$ (i.e. use up all their deposits) then it follows that Market clearing implies that $K_{1}=D_{0} D_{1}$ (i.e. the increase in capital must equal change in deposits), but we also know that the new deposit level is so it logically follows that $\boldsymbol{K}_{\mathbf{l}}-\left(\mathbf{1}-\boldsymbol{t}^{*}\right) \mathbf{- 1 - i}-\boldsymbol{i}-\mathbf{f}^{*}$.

At $T=2$, all consumers receive an extra endowment of $G$ and regulators levy lump sum taxes of $L$ to cover expected shortfalls in deposit insurance. New shareholders decide whether to expend resources to acquire private information about their bank's asset returns at $T=3$. The utility cost of gathering information is exogenously set at c units of consumption. We assume for simplicity that old shareholders as 'insiders' can acquire this private information with virtually little or no cost whatsoever.

Shareholders with private information receive a signal (at $T=2)$ as to whether the bank's asset returns will be above or below the mean return $R$ at $T=3$. Immediately thereafter, consumers find out whether they suffer a liquidity shock (consume early) or not (consume late). Following this, early consumers exchange their financial claims for units of consumption. Shareholders sell their equity to late consumers in exchange for part of the late consumers $T=2$ endowment and

\footnotetext{
${ }^{9}$ It is assumed that there is a single bid and ask price regardless of trade size.

${ }^{10}$ Banks may raise capital either on their own accord or at the demand of the regulator. Although, banks can choose either to raise capital or exit the industry (or be forced to exit if they do not meet capital requirements). For now we assume that capital requirements bind and regulators can credibly enforce them. We can then concentrate on the symmetric outcome where banks raise the same amount of capital.
} 
depositors withdraw their deposits from their banks. Note however, that bank assets do not yield consumption until $\mathrm{T}=3$, thus banks must buy consumption from late consumers to pay for withdraws from early consumers issuing demand deposits to the late consumers in exchange. In aggregate banks simply act as a means for early consumers to trade their deposits to late consumers in exchange for consumption goods at $\mathrm{T}=2$. At the climax of $\mathrm{T}=2$, early consumers consume while it is assumed that late consumers can store (hoard) any residual $\mathrm{T}=2 \mathrm{en}$ dowments with no cost. This ensures that insured deposits will trade at a one for one ratio with consumption at $\mathrm{T}=3 .{ }^{11}$

At $\mathrm{T}=3$, bank asset returns are realized and divided among investors. If a bank is unable to honor its deposits at face value, then it fails and the private charter value is lost; otherwise, the shareholders implicitly consume the private charter value. Finally, late consumers consume. The model is solved recursively. The behavior at $\mathrm{T}=3$ is elementary, so we begin the analysis at $\mathrm{T}=2$.

\subsubsection{Strategic and liquidity trading at $\mathrm{T}=2$}

Old shareholders and new shareholders who gather information at a cost of $\mathrm{c}$ units of consumption receive a signal informing them whether the bank asset returns at $\mathrm{T}=3$ are above or below the mean return $\mathrm{R}$. We call this group of investors informed since they can use this information advantageously to trade shares. Shareholders who suffer liquidity shocks must sell their shares to meet early consumption needs (regardless of whether they are informed or not). As a result, the informed traders might exploit them. We call this group of shareholders liquidity traders (sellers). Note however, that gathering information is a necessary but insufficient condition for a shareholder to be able to act strategically on this information. To be a 'strategic' trader, a shareholder needs to have gathered information as well as be a late consumer ${ }^{12,19}$

There is perfect information on the ask side of the market since only informed shareholders will buy shares. The model has no liquidity buyers. Since informed traders only buy shares if the shares are priced fairly, market makers will be able to infer from the demand for shares (or lack there of) whether returns will be above or below average and set PA accordingly. However, the model does entertain the notion of liquidity sellers, thus, strategic traders can profit from selling shares at bid price when they know that bank returns will be below average..$^{13}$

Let us define $E_{2}^{+}$and $E_{2}^{-}$as the expected value of the bank's equity conditional on asset returns being above and below the mean return respectively. Assuming there is equal probability that asset returns will be above or below

\footnotetext{
${ }^{11}$ Equivalently, we can assume that late consumers are able to invest their residual $\mathrm{T}=2$ endowments in a risk free asset which yields zero net return.

${ }^{12}$ Incidentally, old shareholders are the most likely to be able to trade strategically since they can gather information at no cost, and have the lowest probability of early consumption.
} 
average, the expected value of equity at the end of $\mathrm{T}=1$ (before any information is received) is $E_{1}=\left[\frac{E_{2}^{+}}{2}+\frac{E_{2}^{-}}{2}\right]$ and the standard deviation across realizations is . $\Sigma=\left[\frac{E_{2}^{+}}{2}-\frac{E_{2}^{-}}{2}\right]$ The values of E1 and $\Sigma$ depend on whether or not the banks' promised payments on deposits, RDD1, are above the mean return R. The focus here is on the case where $R_{D} D_{l}<R$, which implies that the bank's ex-ante chance of failure is less than one half, which seems a reasonable assumption. Given this assumption, we have the following: ${ }^{14}$

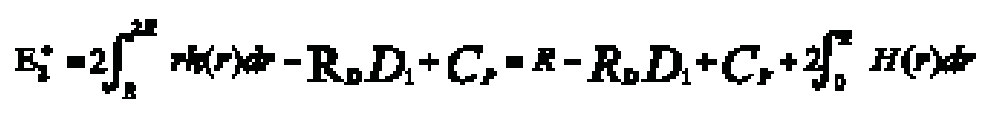

and

$$
\begin{aligned}
E_{2}^{-} & =2 \int_{D_{D} D_{1}}^{R} \ln (\mathrm{r}) \mathrm{dr}-\left(\mathrm{C}_{\mathrm{T}}-R_{D} \mathrm{D}_{1}\right)\left[1-2 H\left(R_{D} D_{1}\right)\right] \\
& =R-R_{D} D_{I}+\mathrm{CP}[1-2 \mathrm{H}(\mathrm{RDD} 1)]-2 \int_{B D}^{R}{ }_{D 1} H(r) d
\end{aligned}
$$

Thus, if a good signal is obtained, the bank survives with certainty, honors dennsits at nar retains private charter value, and the returns exceed the mean by

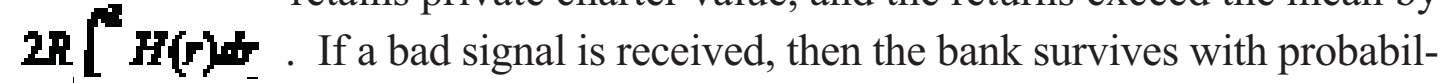
ity $\left[\mathbf{1}-\mathbf{2} \boldsymbol{F}\left(\boldsymbol{R}_{\boldsymbol{g}} \boldsymbol{D}_{\mathbf{3}}\right)\right]$, in which case it honors its deht at par, retains its charter value, and returns are below the mean by $\mathbf{Z}(\mathbf{r}) \mathbf{A}$. It is straightforward to see that:

$$
\text { and } E 1-R-R_{D} D_{1}+C p\left[1-2 H\left(R_{D} D_{1}\right)\right]+\int_{0}^{X_{D} D_{1}} H(r) d r
$$

$$
\mathrm{\Sigma}=C p H\left(R_{D} D_{1}\right)+\int_{0}^{R}-H(r) d r+\int_{R_{n} D}^{R} H(r) d r
$$

We now consider the equilibrium information gathering decision and market clearing price at $\mathrm{T}=2$. Suppose a new shareholder (those who buy shares at $T=1$ ) of type $t$ becomes informed, with probability $t$ they will face a liquidity shock and are forced to sell their stock at the bid price $P_{B}$. Thus, with probability $1-t$ they will be able to act strategically. Half of the time, banks asset returns will be above average, so it will pay to hold on to the shares and receive $E_{2}^{+}$. The rest of the time, bank returns will be below average, in which case they will rationally sell the shares and receive $P_{B}$. Accordingly, their total return is: ${ }^{15}$

\footnotetext{
${ }^{13}$ Short sales are ruled out for simplicity.

${ }^{14}$ Gorton and Winton (2000) consider the case where RDD1 > R, however we abstract from this complication in this paper.
} 


$$
\begin{aligned}
& T_{l}=\frac{\pi_{1}}{N_{1}+N_{1}}\left[P_{P}+\frac{1}{2}(1-t) E_{Y}^{+}+\frac{1}{2}(1-t) P_{I}\right]-\varepsilon \\
& -\frac{N_{1}}{N_{0}+N_{1}}\left[\frac{(1+f)}{2} P_{2}+\frac{(1-f)}{2} E_{2}^{*}\right]-c
\end{aligned}
$$

A new shareholder who does not become informed has probability $t$ of selling their shares at bid price to finance early consumption and has probability 1- $t$ that they will be able to hold onto their shares till maturity and earn $E_{l}$. Thus, their total return is:

$$
R_{1}=\frac{n_{1}}{N_{1}+N_{1}}\left[\mathbb{P}_{1}+(1-t) E_{1}\right]
$$

A rational shareholder will gather information if $T R_{I}$ exceeds $T R_{U}$, which is the same as:

$$
\left.\frac{\#_{1}}{N_{6}+N_{1}} 2-P_{3}-E_{2}^{-}\right]=c
$$

(b)

The bid price PB is the expected value of a share, conditional on it being sold. Now, defining $S$ and $\Lambda$ to be the volume of strategic and liquidity trades respectively, it follows that:

$$
P_{3}=\frac{S E_{i}^{-}+\Lambda E_{2}}{S+\Lambda}=\left[1-\frac{S}{S+\Lambda}\right] E_{\mathrm{L}}=(1-\Lambda) E_{\mathrm{L}}
$$

Consequently, at $T=2$, instead of receiving a price of $E_{1}$, because of their relative lack of information, liquidity sellers receive a discounted price, where ceteris paribus, the discount is increasing both in the relative risk of bank equity $\frac{\mathbf{z}}{\boldsymbol{E}_{\mathbf{1}}}$, and the relative volume of strategic trades $\frac{\boldsymbol{s}}{\boldsymbol{s + \boldsymbol { A }}}$. . Substituting (9) into (8), we have that a new shareholder of type $t$ will gather information if and only if:

$$
\frac{n_{1}}{N_{6}+H_{1}} \frac{1-t}{2} \frac{A}{s+A} \Sigma-c=0
$$

\footnotetext{
${ }^{15}$ Derivations of equations can be obtained upon request.
} 
That is, informed sellers receive a profit over and above the share's true value, which is proportional to the level of risk of bank equity and the relative volume

of liquidity trades $\frac{\mathbf{A}}{\boldsymbol{s}+\boldsymbol{\Lambda}}$

It is possible that some, none, or all new shareholders satisfy (10). Define the ne' $\cdot$ lder with the highest $t$ for whom (10) is satisfied (or $t^{*}$ otherwise) to be $\boldsymbol{t}_{\boldsymbol{z}} \mathbf{E} \boldsymbol{\boldsymbol { t } _ { \text { . } }}$. We can now calculate $\mathrm{S}$ and $\Lambda$. Recalling that informed shareholders sell strategically with probability $\underline{(\mathbf{n - t})}$, and that all old shareholders are informed, then:

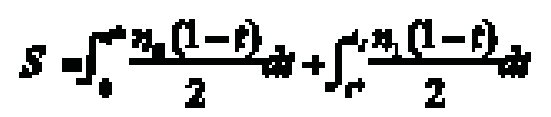

(11)

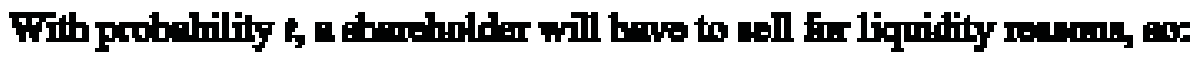

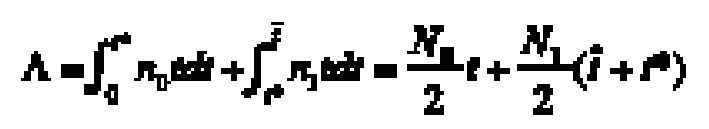

In sum, given the marginal informed shareholder $\mathrm{tI}$, the equilibrium stock price $P_{B}$ at $T=2$ is determined by (9) where strategic trading $S$ is given by (11), and liquidity trading $\Lambda$ is given by (12). The information gathering decision is summarized by the marginal informed shareholder $t_{I}$. If the left hand side of (10) is negative at $t=t^{*}$, then no new shareholders become informed and $t_{I}=\hat{t}$.If the left hand side of (10) is positive at $t=\hat{t}$, then all new shareholders become informed and $t_{l}=\hat{t}$. Otherwise, $\mathrm{tI}$ is a unique value between $t^{*}$ and $\hat{t}$ for which (10) holds with equality, and all new shareholders in $\left[t^{*}, t_{l}\right]$ become informed.

\subsubsection{Equilibrium when banks raise capital at $\mathbf{T}=1$}

We now move from the secondary stock market at $T=2$ to the primary market at $T=1$ in which banks issue additional equity. This section determines the equilibrium issue price for equity $P_{1}$ given that all banks raise the same amount of capital. This in turn determines the banks' cost of capital. As one would expect, $P_{1}$ takes into account the equilibrium at $T=2$ where early consumers who must sell their shares face possible losses to informed shareholders' strategic behavior.

Suppose that all banks raise an amount of capital $K_{1}$ by issuing $N 1$ shares at an issue price of $P_{1}$ per share. Recall that market clearing requires that total deposits fall by the same magnitude as the increase in capital so we have $K_{1}=$ $P_{1} N_{1}=D_{0}=D_{1}$. The new marginal shareholder must be indifferent between buying 
a share at price P1 or holding onto P1 units of deposits and eventually earning $R_{\mathrm{D}} P_{1}$. Since the marginal shareholder depends in part on whether or not they choose to gather information, Gorton and Winton (2000) assume that (i) the cost of gathering information is sufficiently low so that at least some new shareholders choose to acquire information, and (ii) the marginal new shareholder does not become informed. That is, they assume that $t, \in\left(t^{*}, \hat{t}\right)$. Given these assumptions, the typical consumer maximization problem at $T=1$ is tooptimally choose their amount of new shares $\mathrm{n} 1$ and new level of deposits $D_{1}$ to maximize expected utility taking as given the issue price of equity $P_{1}$ and initial level of deposits $D_{0}$. That is, the consumer problem is:

$\operatorname{Mrox} E U\left(C_{2}(t), C_{3}(t)-K_{1}(t)+(1-f) C_{1}(t)\right.$

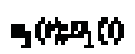

subject to

$$
\begin{aligned}
& 1_{+} C_{1}(t)=R_{D} D_{1}(t)+\frac{N_{3}(f)}{N_{1}+N_{1}}(1-\Delta) E_{1}+G-l \\
& 2 C_{1}(t)-R_{0} D_{1}(t)+\frac{n_{1}(t)}{N_{1}+N_{1}} E_{1}+G-L \\
& \text { 3. } P_{1} n_{1}(t)-D_{0}(t)-D_{1}(t) \\
& \text { 4. } m_{2}(t)=0 \\
& \text { 5. } D_{1}(t)=0
\end{aligned}
$$

The first constraint is an early consumers' budget constraint at $T=2$. They consume by withdrawing deposits at RD per unit, selling their share in equity $\mathrm{n} 1 \frac{n_{1}(t)}{N_{0}+N_{1}}$ at bid price $P_{B}=(1-\Delta) E_{l}$, consuming their $T=2$ endowment $G$, less lump sum taxes $L$. The second constraint is a late consumer's budget constraint at $T=3$, save they do not face potential losses to strategic traders and get the full value of their total equity. Three says that the consumer purchases their new shares with existing deposits. Four and five are non-negativity constraints. The first-order condition yields the following result.

\section{Proposition 1: (Equilibrium and the Cost of Bank Capital at T=1)}

Suppose at $T=1$ all banks raise capital by $K_{1}$, then all consumers with $t<{ }^{\prime} t$ use all their deposits to buy shares such that each buys $n_{1}=\frac{1}{P_{1}}$. shares. Then
the equilibrium price of bank equity $P_{1}$ satisfies 


\section{$P_{1} R_{D}=\frac{1-\hat{t} \Delta}{N_{0}+N_{L}} E_{1}$}

Proof. See Gorton and Winton (2000).

As noted, the new marginal shareholder must be indifferent between buying one share out of $N_{0}+N_{1}$ shares or holding onto $P_{l}$ units of deposits, eventually earning $R_{\mathrm{D}} P_{1}$ (the value of the former is given by the right hand side). This marginal shareholder's indifference condition is what yields equation (14). Also, because consumers are risk neutral, all inframarginal shareholders strictly prefer holding portfolios consisting only of deposits.

Proposition 1 states that, due to the presence of strategic traders when some consumers face a liquidity shock at $T=2$, knowing this at $T=1$, depositors demand mark up in return of $\frac{R_{D}}{1-\hat{t} \Delta}$ per dollar of deposit to induce them to buy new shares (they demand a lower price per share or equivalently a higher expected return on equity in compensation). Since banks need to raise $K_{1}$ dollars of equity in total, the aggregate, expected value of new shareholders' share of the total value of equity is $\frac{R_{0} K_{1}}{1-\hat{t} \Delta} \cdot 25$

\subsubsection{Social and private welfare at $T=1$}

We now turn the analysis to the incentives of regulators and banks to raise capital at $T=1$. For now, it is assumed that regulators have the objective of maximizing social welfare, that is, maximize aggregate welfare of all agents assigning equal importance to the welfare of shareholders and depositors. Define $W_{S}\left(K_{P}\right)$ to be the aggregate, expected, social welfare function as a function of the new amount of capital raised at $T=1$. In this model, raising capital is beneficial to social welfare because it reduces the probability of bankruptcy. Thus, net of information gathering costs we assume that raising capital improves social welfare. ${ }^{2}$ More precisely, we are assuming that the social welfare function that regulators are attempting to maximize is increasing in capital. That is, $\frac{d W_{s}}{d K_{1}}>0$ with $\frac{d^{2} W_{s}}{d K_{1}^{2}}<0$

The decision as to whether an individual bank raises capital or not is made by the banks old shareholders (those who already held shares at $T=0$ ). Assume that shareholders act to maximize their private welfare $W_{P}\left(K_{I}\right)$, which is a function of the amount of capital raised at $T=1$. It has been shown that raising capital is costly for banks and we assume that these costs outweigh the potential benefits. That is, we assume the combination of liquidity effects and strategic trading means that issuing equity is always bad for old shareholders. Intuitively, due to the existence of negative externalities from bank failure, debt overhang effects created 
by deposit insurance (Myers, 1977) and the combined costs of liquidity and strategic trading effects of equity issuance makes issuing additional equity to support higher capital standards always less attractive for shareholders than it is for the regulator. That is $\frac{d W_{P}}{d K_{1}}\left\langle 0\right.$ with $\frac{d W_{P}}{d K_{1}{ }^{2}}<0 .{ }^{16}$

The preceding discussion has presented the baseline of Gorton and Winton (2000) model where we were able to show that increasing capital requirements leads to a discount on the newly issued share price, or equivalently, an increase in the cost of bank equity capital. ${ }^{17}$ It was also assumed that the social incentive to increase capital is greater than that of private incentives, which naturally create tensions between regulators and banks when setting capital requirement standards. In this setting, we next analyze the impact of capture and competition in regulation, linking it to regulatory forbearance.

\subsection{Capture, competition and forbearance in regulation}

In the preceding sections, we presented a model in which the cost of bank equity capital is endogenously determined in general equilibrium. An important assumption made was that regulatory objectives were to maximize aggregate social welfare WS (K1), and that regulators were able to enforce banks to raise an exogenous amount of capital K1. In this section, I allow for differences in regulatory objectives that endogenizes the exercised levels of forbearance, and therefore, the levels of capital that banks must raise. I define forbearance to be regulators reneging of previously tough policies, or simply, forbearance is the lax enforcement of capital requirements.

We begin the analysis in this section by appealing to two facts. First, the political economy of regulation implies that some regulators are more closely aligned with an interest group, such as bank owners. This 'public choice' or 'capture' view emphasizes the important role of interest groups in determining regulatory outcomes. Although most authors attribute this intellectual wisdom to Stigler (1971) and later Peltzman (1976) and Becker (1983), its origin has deep roots and can be traced back to Marx who argued that big businesses sought and paid for control of important economic institutions (Laffont and Tirole, 1991). Empirical evidence supporting this hypothesis can be found in Kane (1990) who documented proof of regulatory capture in the United States, the Savings and Loans debacle, and White's (1982) commentary on the evolution of banking regulation in the United States. More recently, Slinko et al. (2004) provide evidence of capture across a number of industries in Russia.

\footnotetext{
${ }^{16}$ Gorton and Winton (2000) show that information-gathering costs are a dead weight loss.

${ }^{17}$ Gordon and Winton (2000) derive specific functional forms for WS (K1) and WP (K1).
} 
Second, to the extent that regulators are concerned about the old shareholders of their domestic banks, they may lower regulatory requirements in order to provide them with an advantage over foreign banks (Acharya, 2003; Dell, Ariccia, and Marquez, 2001; Holthausen and Rønde, 2003). Niskanen (1971) amongst others provide another rationale for competition in regulation. Given the possibility of international banks engaging in regulatory arbitrage by switching to lower-cost regulators to reduce the costs of compliance, for relatively stringent (high-cost) regulators, this regulatory competition will see their regulatory market shares eroded. Accordingly, in view of protecting their market share, these high-cost regulators will either reduce their regulatory burdens or increase regulatory subsidies. This type of regulatory race to the bottom or competition in laxity as regulators attempt to attract business into their domain with ever more large regulatory standards has been the catalyst for arguments in favor of international harmonization of regulatory standards before reaching the bottom of the barrel.

Although this issue is not formally dealt with until the next section when multiple economies are incorporated into the model, it should be noted here that this competition in laxity can also enter the regulator's objective function. Accordingly, we generalize the regulator's objective function to one that maximizes the weighted average of aggregate welfare for old shareholders and aggregate social welfare, with weights $\theta$ and $(1-\theta)$ respectively, thus:

\section{$W_{\theta}\left(K_{1}\right)-\theta F_{7}\left(K_{1}\right)+(1-\theta) W_{f}\left(K_{1}\right)$}

The parameter $\theta \mathrm{E}[0,1]$ can be thought of as the degree of regulatory capture (or regulatory competition). If $\theta=1$, then $W_{\theta}\left(K_{1}\right)=W_{1}\left(K_{1}\right)$, which corresponds to a situation where regulators are completely captured and care only about existing shareholders. While $\theta>0$ implies that $W \theta\left(\mathrm{K}_{1}\right)=\mathrm{W}_{\mathrm{S}}\left(\mathrm{K}_{1}\right)$, which represents the normative case of aggregate social welfare maximization described thus far in the paper. Because of government ownership of banks, government influences over regulatory agencies as well as the time inconsistency in enforcing ex-ante optimal regulatory policies, which typically benefits bank owners, many regulators would be classified as having a weight of $\theta>0$.

We recognize the impact of regulatory capture or competition (or some combination of both) on the exercised level of forbearance and consequently the amount of capital that regulators require banks to raise at $\mathrm{T}=1$ in the following result:

\section{Lemma 1 (Capture and forbearance)}

As the degree of regulatory capture increases, the level of exercised forbearance increases, and thus the amount of capital that banks are required to raise by regulators decreases. That is, the amounts of capital banks are required to raise at $\mathrm{T}=1$ is decreasing in regulatory capture or $\mathrm{dK} 1 \mathrm{~d} \theta<0$. 
Proof. See Appendix.

The intuition for this result is straightforward. We assumed that the increase in aggregate social welfare for a given increase in the level of capital is always greater than the change in aggregate private welfare. Therefore, as regulatory capture increases, the regulators objective function becomes increasingly aligned with that of the old shareholders who have a preference for lower capital requirements.

Whether it is because regulators are more captured or are competing more intensely (or some combination of both), this setup allows us to analyze situations where regulators from different countries have differing 'tastes.' for regulation and place greater or less emphasis on existing bank shareholders versus aggregate social welfare. This is the issue I take up in the rest of the paper.

\subsection{Two-Country Model}

Financial integration generates the potential for 'spillovers' from one country to another arising from differing regulatory practices. To study these potential spillovers from one country's regulations to other countries and their regulations, I extend the model to two countries.

Consider two countries, A and B. The banking sector in each country consists of a continuum of homogeneous banks, a continuum of risk neutral consumers uniformly distributed on $[0 ; 1]$, many competitive, risk neutral, market makers, and a regulator, as in the single economy case already presented.

Banks operate across countries, offer the same exogenous deposit rate $\mathrm{R}_{D}$, and have equal access to deposit and lending opportunities. There are no restrictions on whether consumers invest (buy shares or deposits) in their domestic or foreign bank. The consumers in the two countries suffer independent liquidity shocks, however, these shocks occur with the same probability $t$ in each country. Regulators may adopt regulatory policies with differing levels of forbearance toward the banks chartered in their respective countries. The differing levels of forbearances reflect the degrees of capture in each country and are denoted $\theta_{\Lambda}$ and $\theta_{\mathrm{B}}$, respectively.

Under this setting, I ask myself what kind of effect the level of capture in country A will have on the cost of equity capital of the banks in country B. First, I assume that the regulator in country $\mathrm{A}$ is relatively more captured, that is $\theta_{\mathrm{A}}>\theta_{1:}$. In this situation, I show that the cost of equity capital for country B in banks is decreasing in the level of capture (forbearance) of country A's regulator. This effect is called the spillover from country A to country B. 


\section{Lemma 2 (The new marginal shareholder)}

Ceteris paribus, if $\theta_{\mathrm{A}}>\theta_{\mathrm{B}}$ then $K_{1}^{A}<K_{1}^{B}$ and the new marginal shareholder for banks chartered in country B is $t_{B}=\frac{\hat{t}_{A}=\hat{t}_{B}}{\hat{t}_{B}}$

\section{Proof: See Appendix.}

Allowing for a difference in forbearance between the two countries captures the institutional reality that although the Basel Accord has taken large steps in attempting to harmonize capital standards globally, individual countries have maintained large discretion on the determination of which assets can be used to meet capital requirements ${ }^{18}$

Lemma 1 states that the exercised level of forbearance increases as the level of regulatory capture increases resulting in a lower required increase in bank capital. It follows that if the regulator in country A is relatively more captured then they must also exercise a higher level of forbearance, thus demanding a lower increase in bank capital at $\mathrm{T}=1$. In other words, assuming $\theta_{\mathrm{A}}>O_{\mathrm{B}}$ implies that $K_{1}^{A}<K_{1}^{B}$. It is straightforward to see from proposition 1 that if these two countries were segmented then the cost of capital in country A will be lower than the cost of capital in country B. This result follows from the fact that because regulator $\mathrm{A}$ is relatively more captured and therefore requires less capital to be raised at $\mathrm{T}=1$, the new marginal shareholder in country $\mathrm{A}, \wedge \mathrm{tA}$, has a lower probability of suffering a liquidity shock relative to country $\mathrm{B}$, and thus, values bank equity more highly than the marginal shareholder in country $\mathrm{B},{ }^{\wedge} \mathrm{tB}$.

However, when the two countries are financially integrated, then banks from country B can (in a cost of capital sense) benefit from country A's lax enforcement of capital requirements. Recall that when the countries are segmented, then $\hat{t}_{A}<\hat{t}_{B}$. It follows that, relative to country A, there must be $\hat{t}_{B}>\hat{t}_{A}$ more consumers in country $\mathrm{B}$ who become new shareholders at $\mathrm{T}=1$. Given that consumers in both countries are identical, conditional on their probability of sobering a liquidity shock, they will have the same valuation of the banks in country B.

Consequently, when the countries become integrated, it is rational for banks in country B to issue new stock to consumers who value it most highly (have a lower probability of consuming at $\mathrm{T}=2$ ) regardless of whether they are from country A or B. Accordingly, instead of issuing all new equity only to consumers in country B, banks in country B will raise capital domestically up to a level that is equal to the amount that country A's banks raise (domestically), and then raise the additional required amount of capital demanded by the regulator in country

\footnotetext{
${ }^{18}$ Gorton and Winton (2000) argue that actions by national countries to broaden the definition of capital has considerably weakened capital adequacy standards and led to significant heterogeneity in the definition of capital across countries
} 
B. That is, the amount of capital over and above the amount demanded by the regulator in country A by issuing new equity to consumers in both countries. In fact, banks in country B will raise exactly half of the remaining required capital from consumers in country B and the other half from consumers in country A. In other words, the new marginal shareholder for country B's banks will lie exactly half way between the new marginal shareholder for country $A, \hat{t}_{A}$, and the new marginal shareholder for country $B$ when the countries are segmented, ${ }^{\wedge} \mathrm{tB}$. Explicitly, the new marginal shareholder for country B's banks when the countries are integrated will be $\tilde{t}_{B}=\hat{t}_{A}+\widetilde{t}_{B 2}<\hat{t}_{B}$

Recall however that this mark up in the cost of capital demanded by new shareholders at $\mathrm{T}=1$ stems from the presence of strategic traders when some consumers face a liquidity shock at $\mathrm{T}=2$. So, aside from the marginal consumer's probability of suffering a liquidity shock (which determines the marginal valuation of new bank equity), we also need to consider the possible affect that this spillover of depositors from country A to country B may have on the lemons discount on the share price at $\mathrm{T}=2$ in the secondary market. Remember that the liquidity sellers receive a discounted bid price PB determined by equation (9) where the discount was given by $\Delta=\frac{\mathrm{s}}{\mathrm{s}+\mathrm{A}} \frac{\sum}{\mathrm{E}_{\mathrm{i}}}$. With this in mind, we have the following result.

\section{Lemma 3 (Equity Discount at $\mathbf{T}=\mathbf{2}$ when Countries are Integrated)}

Relative to the scenario where the countries are financially segmented, with an un- changed relative risk of the bank in country $B, \frac{S_{B}}{S_{n}+\wedge_{B}}$, financial integration decreases the volume of liquidity trades, $B$, proportionately more than the decrease in volume of strategic trades, $\mathrm{SB}$, resulting in the relative volume of strategic trades, $\mathrm{SB} \mathrm{SB}+$ B , increasing. Consequently, the $\mathrm{T}=2$ discount for country B.s bank equity increases. That is economies discount.

Proof: See Appendix.

It is straightforward to see that the relative risk of the bank in country B does not change. The expected value of equity at the end of $\mathrm{T}=1, \mathrm{~EB}_{1}$, and the standard deviation across realisations, $\Sigma_{B}$, are determined by equations (4) and (5) respectively. We can see from equations (4) and (5) that the only endogenous factor that will change the expected return or risk of the .rm is the new level of deposits that they hold at $\mathrm{T}=1, \mathrm{D}_{1}$, all other variables are assumed exogenous. Although integration allows banks in country B to issue their stock to consumers who value it most highly in both countries, the absolute number of consumers who give up their deposits in exchange for equity remains unchanged, and thus, the new deposit level is unchanged post integration.

Integration means that banks in country B will sell some of its $\mathrm{T}=1$ equity to consumers in country A. This reduces the probability of the marginal (and 
inframarginal) shareholder suffering a liquidity shock and collectively decreases the aggregate probability that new shareholders will have to consume early leading to a reduction in the volume of liquidity traders. This reduction in the volume of liquidity traders will, ceteris paribus, reduce the incentive for new shareholders to gather information as given by equation (10). Of course, this leads to a reduction in the number of strategic traders. However, one would logically expect the fall in volume of strategic traders to be smaller than the fall in the volume of liquidity traders. This is because we originally assumed that there was a unique shareholder for which the information gathering condition - equation (10) - held with equality. That is, the new marginal informed shareholder lay somewhere between the old marginal shareholder and the new marginal shareholder. Thus, it would be logical to expect that post integration the marginal shareholder would once again locate somewhere between the new marginal shareholder and the old marginal shareholder which determines the number of strategic traders. Accordingly, the $\mathrm{T}=2$ discount on country B's bank equity will be higher.

The preceding discussion established that post integration the marginal shareholder $\sim \mathrm{tB}$ has a lower probability of suffering a liquidity shock than the segmented economies marginal shareholder ${ }^{\wedge} \mathrm{tB}$, and therefore, values country B's bank equity more highly, thus demands a smaller discount on the issue price or equivalently a lower mark up in the expected return (cost of capital) in compensation. On the other hand, the increase in the $\mathrm{T}=2$ discount will lead to an increase in the cost of capital. These two effects offset each other, so before any result can be presented we need to make the following qualifying assumption. It is assumed that the effect on the cost of capital from the reduction in the marginal shareholder's probability of consuming early is greater than the effect of the increase in the $\mathrm{T}=2$ discount.

This assumption seems plausible since the reduction in the new marginal shareholder's probability of suffering a liquidity shock enters directly into the cost of capital calculation as given by equation (14), while the increase in the $\mathrm{T}=$ 2 discount is less direct. The increase in the $\mathrm{T}=2$ discount comes about because of the change in the new marginal shareholder's probability of consuming early, which then reduces the number of liquidity traders, then impacts on the number of new shareholders who choose to gather information, which finally reduces the volume of strategic trades before the increase in the $\mathrm{T}=2$ discount enters the cost of capital calculation. With this in mind, we have the following result.

\section{Proposition 2 (International Spillover)}

Ceteris Paribus, in financially integrated economies, the cost of capital for banks chartered in country B is decreasing in the level of capture of country A.s regulator. 
Proof. See Appendix.

This result tells us that, other things being equal, as the regulator in country A becomes more captured or is competing more intensely with other regulators to either maintain their regulatory market share or favor banks chartered in their country or some combination of all three. Whatever the reason, the level of exercised forbearance increases. With this, the amount of capital that the regulator in country A requires to be raised declines. By lemma 2 this leads to a reduction in the probability of the new marginal shareholder of country B's banks experiencing a liquidity shock while lemma 3 suggests that the discount on country $\mathrm{B}$ 's bank equity at $\mathrm{T}=2$ increases. In aggregate, it is argued that the former effect outweighs the latter leading to an overall decrease in the cost of bank equity for banks chartered in country B. Specifically, we argued earlier that in a single economy model proposition 1 tells us that due to presence of strategic traders when some consumers face a liquidity shock at $\mathrm{T}=2$, knowing this at $\mathrm{T}=1$, depositors demand a marked up expected return (cost of capital) of $\frac{R_{D}}{1-\hat{f}_{B} A_{B}}$ per dollar of deposit to induce them to buy shares. Proposition 2 tells us that when countries are financially integrated and capital regulations are not credibly enforceable, then differences in regulatory capture and forbearance lead to depositors demanding a smaller mark up on the cost of capital of $\frac{R_{D}}{1-\hat{t}_{B} \Delta_{B}}$ per dollar of deposits, where $\widetilde{t}_{\mathrm{B}} \Delta_{\mathrm{B}}<\hat{\mathrm{t}}_{\mathrm{B}} \Delta_{\mathrm{B}}$. This discussion also gives us the following welfare result.

\section{Corollary 1 (International Spillover and Welfare)}

Relative to the case when the two countries are segmented, the spillover of depositors from country A to country B which results in the reduction in the mark up in the cost of capital demanded by new shareholders of B's banks leads to an increase in both private and social welfare in country B. However, there is no change in private welfare in country A and the impact on social welfare in country A is ambiguous.

Since consumers are risk neutral, summing across all shareholders the expected trading profits of strategic traders cancels out with the expected losses of liquidity traders, that is, trading is a zero sum game. Nonetheless, since old shareholders have the lowest probability of suffering a liquidity shock they are the best placed to trade strategically on their private information. Consequently, on average, old shareholders have a net trading gain while new shareholders have a net trading loss. Recall our assumption $\frac{\mathrm{dWp}}{\mathrm{dK}_{1}}<0$.

Consequently, although old shareholders face a net trading gain at $\mathrm{T}=2$, we implicitly assume that the discounted share price (higher cost of capital) on the issue of new equity at $\mathrm{T}=1$ more than offsets the $\mathrm{T}=2$ trading gains ${ }^{19}$

${ }^{19}$ Gorton and Winton (2000) show that this is indeed the case. 
With this in mind, lemma 3 tells us that the spillover of depositors from A to $\mathrm{B}$ reduces the relative volume of liquidity trades and thus reduces expected trading profits to old shareholders. This effect is however, countered by the reduction in the aggregate discount on new equity (Proposition 2) and by assumption, the reduction in the aggregate discount on new equity will be greater than the fall in the expected trading profits (including trading costs), leaving the old shareholders in country B better off, post integration. Social welfare in country B also increases due to a reduction in the aggregate cost of gathering information since there is a decline in the number of consumers in country B who firstly, buy new equity, and secondly satisfy equation (10), choosing to become informed.

There is no change in the level of capital held by A's bank's post integration, nor is there a change in A's new marginal shareholder's probability of suffering a liquidity shock. Thus, the valuation of A's banks remains constant. On the other hand, some depositors in country A now hold new equity in country B's banks, leading to a fall in social welfare. This occurs for two reasons. First, the new shareholders of B's banks who belong to country A have the highest probability of suffering a liquidity shock and are thus more likely going to be exploited by B's old shareholders. They have an expected net trading loss while B's old shareholders have a net expected trading profit. Second, some of B's new shareholders in country A will choose to gather information, which as previously mentioned is a dead weight loss, imposing a further welfare cost on country A. This negative impact on social welfare in country A must be weighed up with a positive spillover that arises from the fact that some depositors in country A now hold shares in B's banks which are less likely to fail than banks in country A. These contrasting influences leave the impact on the social welfare of country A ambiguous. Two qualifying points are in order before concluding this section.

First, in a world where countries are symmetric and a bank's investment decision (risk taking) is exogenous, capital adequacy requirements have no effect on bank risk taking incentives. This lack of flexibility is the primary source of spillover of depositors from A to B.30 Of course, if we were modeling the investment side of the story, then lower capital standards will potentially induce greater risk taking by A's banks leading to negative spillover from A to B. Though whether capital regulations actually reduce bank risk taking is far from being agreed upon. (See for example Kahane (1977), Koehn and Santomero (1980), Lam and Chen (1985), Kim and Santomero (1988), Flannery (1989), Genotte and Pyle (1991), Rochet (1992), Besanko and Katanas (1996), and Blum (1999).

Second, we have established that regulation adopted by country A has an externality on the banks in country B. If each regulator is concerned only about maximizing their own welfare function, $\mathrm{W}_{\text {, }}$, this externality will in general, not be internalized in the absence of coordination. The question we need to ask (similar in vain to the conclusions reached by Acharya, 2003; Dell, Ariccia and Marquez, 2001; Holthausen and Rønde, 2003) is whether or not both countries increase their 
forbearance, thereby, producing welfare externalities for the other country, potentially a new equilibrium outcome. That is, will regulators race to the bottom in an attempt to either promote their domestically chartered banks or protect their own regulatory market share? This question is addressed and formalized below.

\subsection{A race to the bottom?}

The previous discussion was made on ceteris paribus grounds. However, when regulators have discretionary powers, they can respond to regulatory choices of other regulators. The literature addressing this issue has to the best of my knowledge has almost unanimously concluded on the lines that, when responding to lax financial regulations in another country, regulators will always choose to reduce regulatory requirements, leading to the so called race to the bottom or regression to the worst regulation.

In this section, I address whether the spillover caused by financial integration presented in the preceding discussion will lead to increased forbearance on a global scale. The assumptions in the previous section remain here, so the two countries are identical save that country A is more captured than country B, or $\theta_{\mathrm{A}}>\theta_{\mathrm{B}}$. Given the potential for spillovers to occur, each independent regulator's welfare function now depends not only on their chosen level of capture or forbearance (and hence level of capital required to be raised at $\mathrm{T}=1$ ), but also on the level of capture in the opposing country. Hence, the maximization problem for regulator B is to choose optimally their level of capture given that regulator A has optimally chosen its level of capture. We see that:

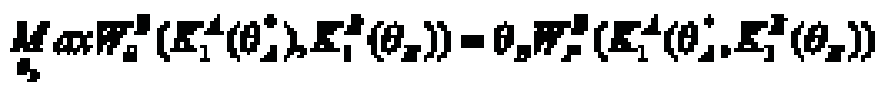

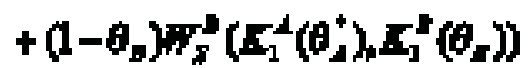

With this in mind, what is B's optimal response to A's lax enforcement of capital requirements? We have the following result:

\section{Proposition 3 (No Race to the Bottom)}

In equilibrium, the regulator in country $\mathrm{B}$ decreases capture and thus forbearance upon the increase in the capture of the regulator in country A. That is @_B @_A $<0$.

\section{Proof: See Appendix.}

This is a striking result and is in stark contrast to any conclusion previously reached addressing this issue. This result states that, from a cost of capital point of view, instead of reacting to A's laxity with an increase in its own forbearance vis-à-vis capital requirements, regulators in country $\mathrm{B}$ will in fact become less captured, and thus be less forbearing towards banks chartered in country B, 
resulting in a demand of a higher level of capital to be raised at $\mathrm{T}=1$.

Intuitively, this proposition holds for two reasons. Relative to the segmented country scenario, integration increases private and social welfare effects of a chosen level of capture. It follows that for country B to reap as much benefit from integration as possible it makes sense for regulator B to align itself less with bank shareholders and demand stricter capital requirements. Second, the spillover of depositors from A to B increases the foreign ownership of B's banks. One would logically expect that domestic bank regulators to be less concerned about shareholders the higher the fraction of foreign ownership, consequently putting a greater weighting on social welfare and demand higher capital levels.

This result casts doubt (at least in the context of this model) on the argument that independent regulators will react to lax regulations of opposing countries by weakening their own regulatory standards. I have demonstrated here that it is at least theoretically possible that a country will react to lax regulations of other countries by strengthening their own regulations.

\section{Conclusion}

In recent years, the progressive integration of international financial markets has brought with it an increasing focus on the coordination of regulations across national borders. This trend has spurred a debate on the costs and benefits of the international harmonization of banking regulations. The Basel Capital Accord of 1988 provides a case in point in regard to the voracity of the debate between the opposing sides. This paper adds to this debate by investigating the now common claim by banks that the regulations they face induce an increase in risk .a regulatory risk.

The paper defines regulatory risk to be regulations that lead to an increase in the cost of equity capital. Accordingly, the cost of capital is modeled in a general equilibrium setting where demand deposits serve a unique role in providing an efficient medium of exchange. Although bank capital reduces the probability of failure, bank equity is relatively sensitive to information, thus making it a poor hedge against liquidity risk.

Consumers initially hold deposits to the extent they need coverage against liquidity shocks. Those who have the highest probability of being early consumers optimally choose to hold deposits. A system wide increase in capital will, in the context of the model, force some depositors to exchange their deposits for their less preferred bank equity. This increases the probability that the marginal shareholder will suffer a liquidity shock and thus leads to a mark up on the cost of capital. However, when regulatory standards differ across countries, a spillover of depositors from the lax to more stringent country leads to a reduction in the cost of capital mark up demanded by new shareholders for the stricter country. The bank belonging to the country with stricter enforcement of regulatory standards 
is, in effect, able to diversify their new equity issuance across countries by selling their shares to consumers with the lowest risk of suffering a liquidity shock.

This result suggests that an international regulatory agreement such as the Basel Capital Accord that imposes uniformity on capital requirements may indeed lead to a higher cost of capital for banks and thus induce greater regulatory risks relative to a decentralized solution. It suggests that the claims made by banks and other financial institutions are at least a theoretical possibility.

Another interesting result was the finding that countries will respond to lax enforcement of regulations by neighboring countries by strengthening their own regulatory standards. This result is in stark contrast to the almost unanimous conclusion reached by other authors tackling this issue that national regulators will react to lax regulations of opposing countries by weakening their own regulatory standards leading to the commonly coined phrase .a race to the bottom vis à vis regulatory standards. The findings of this paper support the arguments of the regulated entities. However, it does not go so far as to make a value judgment as to whether a decentralized approach to capital adequacy regulation is optimal relative to the harmonizing of capital standards or vice versa. It may be the case that a unified framework such as Basel is optimal, but it is also possible that banks in some countries are more efficient and stable than others, thus necessitating differing regulatory standards. There is no reason a priori why we should choose the centralized solution over the decentralized one and vice versa. The paper simply presents testable implications that warrant empirical investigation, only in conjunction with comprehensive empirical studies will the tensions between regulators and the regulated firms are resolved.

Acknowledgement: This article is an edited version of one of the three best papers selected after blind review process at the $17^{\text {th }}$ FMA-Asian Finance Association Meeting, Auckland, New Zealand, 2006. The author is grateful for the reviewer's editorial comments, which assisted the editors to revise my original version of this paper. All remaining errors are my responsibility.

Author statement: Phong T. H. Ngo, School of Economics, HW Ardnt Building 25A, Australian National University, ACT 0200, Australia. Phone: +612-61254487. Email: phong.ngo@anu.edu.au. The paper benefited from the comments given by Tom Smith, Chris Jones, Shane Evans, Colleen Cassidy, Pornpen Sodsrichai and seminar participants at the Australian Prudential Regulation Authority, School of Finance and Applied Statistics (ANU) and the CBE/APSEG seminar series at the ANU. This research was funded by the generous support of an ANU Research Scholarship as well as the Brian Gray Scholarship which is jointly funded by the Australian Prudential Regulation Authority and the Reserve Bank of Australia. 


\section{References}

Acharya, V. V., (2003). Is the International Convergence of Capital Adequacy Regulation Desirable? The Journal of Finance 58: 2745-2781.

Berger, A. N., R. J. Herring and G. P. Szego (1995). The Role of Capital in Financial Institutions, Journal of Banking and Finance 19: 257-276.

Becker, G. S., (1983). A Theory of Competition Among Pressure Groups for Political Influnce, Quarterly Journal of Economics 98: 371-400.

Besanko, D., and G. Katanas (1996). Do Capital Adequacy Requirements Reduce Risk in Banking? Journal of Financial Intermediation 5: 160-183.

Blum, J., (1999). Do Capital Adequacy Requirements Reduce Risks in Banking? Journal of Banking and Finance 23: 755-771.

Boyd, J. H., S. Kwak and B. D. Smith (2000). Banking Crises: What Comes After?. Mimeo, University of Minnesota, Department of Finance (Carlson School of Management).

Cone, K., (1983). Regulation of Depository Institutions. Ph.D. Thesis, Standford University.

Dell.Ariccia, G., and R. Marquez (2001). Competition Among Regulators and Credit Market Integration, Working Paper, University of Maryland.

Diamond, D. W., and P. H. Dybvig (1983). Bank Runs, Deposit Insurance and Liquidity, Journal of Political Economy 91: 401-419.

Dollar, D., and A. Kraay (2000). Growth is Good for the Poor. Mimeo, The World Bank.

Flannery, M., (1989). Capital Regulation and Insured Banks. Journal of Monetary Economics 24: 235-258.

Furlong, F. T., and M. C. Keeley (1989). Capital Regulation and Bank Risk Taking: A Note, Journal of Banking and Finance 13: 883-891.

Genotte, G., and D. Pyle (1991). Capital Controls and Bank Risk, Journal of Banking and Finance 15: 805-924.

Gorton, G., and G. Pennacchi (1990). Financial Intermediaries and Liquidity Creation, The Journal of Finance 45: 49-71.

Gorton, G., and A. Winton (2000). Liquidity Provision, Bank Capital and the Macroeconomy, Working Paper 9806, University of Minnesota, Institute of Financial Studies (Carlson School of Management).

Grinblatt, M. S., and S. A. Ross (1985). Market Power in a Securities Market with Endogenous Information, Quarterly Journal of Economics 100: 11431167.

Grout, P., (1995). The Cost of Capital in Regulated Industries in Regulatory Challenge, edited by M. Bishop, J. Kay and C. Mayer, Oxford University Press, Chapter 16 pp.386-407. 
Hoggarth, G., R. Reis and V. Saporta (2001). Costs of Banking System Instability: Some Empirical Evidence, Working Paper, Bank of England.

Holthausen, C., and T. Rønde (2003). Cooperation in International Banking Supervision, Working Paper 2004-02, Centre for Industrial Economics, Institute of Economics, University of Copenhagen.

Jacklin, C., (1987). Demand Deposits, Trading Restrictions, and Risk Sharing, in E. D. Prescott and N. Wallace, (Eds) Contractual Arrangements for Intertemporal Trade, University of Minnesota Press, Minneapolis.

Kahane, Y., (1977). Capital Adequacy and the Regulation of Financial Intermedi aries. Journal of Banking and Finance 1: 207-218.

Kane, E. J., (1990). Principle-agent Problems in the S\&L Salvage, The Journal of Finance 45: 755-764.

Kaufman, G. G., (1991). Capital in Banking: Past Present and Future, Journal of Financial Services Research 5: 385-402.

Keeley M. C., and F. T. Furlong (1990). A Re-examination of Mean Variance Analysis of Bank Capital Regulations, Journal of Banking and Finance 14: 69-84.

Kim, D., and A. M. Santomero (1988). Risk in Banking and Capital Regulation, The Journal of Finance 35: 1219-1233.

Koehn, M., and A. M. Santomero (1980). Regulation of Bank Capital and Portfolio Risk, The Journal of Finance 35: 1235-1250.

Kyle, A. S., (1985). Continuous Auctions and Insider Trading, Econometrica 53: 1315-1336.

Lafont, J., and J. Tirole (1991). The Politics of Government Decision Making: A Theory of Regulatory Capture, The Quarterly Journal of Economics 106, 1089-1127.

Lam, C. H., and A. H. Chen (1985). Joint Effects of Interest Rate Deregulation and Capital Requirements on Optimal Bank Portfolio Adjustments, The Journal of Finance 45: 563-575.

Levine, R., (1997). Financial Development and Economic Growth: Views and Agenda, Journal of Economic Literature 35: 688-726.

Myers, S. C., (1977). Determinants of Corporate Borrowing, Journal of Financial Economics 5: 147-175.

Niskanen, W. A., (1971). Bureaucracy and Representative Government, AldineAtherton: Chicago.

Peltzman, S., (1976). Towards a More General Theory of Regulation, Journal of Law and Economics 20: 229-263.

Rochet, J., (1992). Capital Requirements and Behaviour of Commercial Banks, European Economic Review 36: 1137-1178. 
Slinko I., E., Yakovlev and E. Zhuravskaya (2004). Laws for Sale: Evidence from Russia, Mimeo, Stockholm School of Economics; Center for Economic and Financial Research in Moscow.

Summer, M., (2002). Banking Regulation and Systematic Risk.. Working Paper 57, Oesterreichische National Bank.

Stigler, G. J., (1971), .The Theory of Economic Regulation, Bell Journal of Economics and Management Science 2: 3-21.

Wagster, J. D., (1996) Impact of the 1988 Basel Accord on International Banks, The Journal of Finance 51: 1321-1346.

White, E. N., (1982), .The Political Economy of Banking Regulation, 1864-1933, Journal of Economic History 42: 33-40. 


\section{Appendix: Proofs}

Proof. (Lemma 1) Consider the regulator's unconstrained design problem given by (15). A regulator chooses a level of capital $\mathrm{K}_{1}$ in order to maximize their welfare function $\mathrm{W}_{\mathrm{p}}(\mathrm{K} 1)$ given the level of capture $\theta$. The first order condition yields

$$
\frac{d W}{d r_{1}}=\theta \frac{d W_{7}}{d T_{1}}+(1-\theta) \frac{d T_{1}}{d T_{1}}=0
$$

$$
\frac{d^{2} W_{0}}{d K_{1}} \frac{d K_{1}}{d \theta}=\frac{d F_{2}}{d F_{1}}+\theta \frac{d^{2} W_{2}}{d K_{1}^{2}} \frac{d T_{1}}{d \theta}
$$

$$
\begin{gathered}
+(1-\theta) \frac{d^{2} W_{t}}{d K_{1}^{2}} \frac{d K_{1}}{d \theta}-\theta \frac{d W_{1}}{d K_{1}} \\
=\frac{d K_{1}}{d \theta}\left[\theta \frac{d^{2} W_{I}}{d K_{1}^{2}}+(1-\theta) \frac{d^{2} W_{d}}{d K_{1}^{2}}\right] \\
+\frac{d W_{P}}{d K_{1}}-\theta \frac{d W_{I}}{d K_{1}} \\
=0
\end{gathered}
$$

(A)

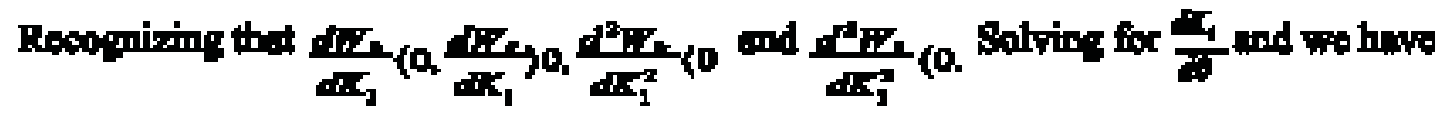

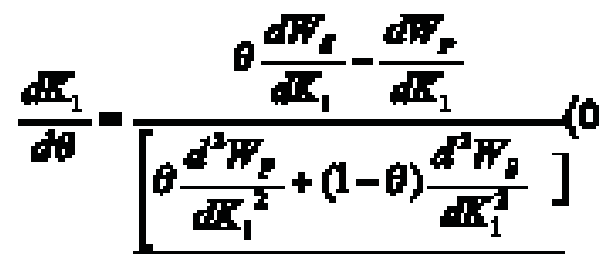

(A)

Proof. (Lemma 2) Suppose that $\theta \mathrm{A}>\theta$ B then by lemma $1 \mathrm{~K}_{1}^{\mathrm{A}}<\mathrm{K}_{1}^{\mathrm{B}}$. Consider first the case where the two countries are segmented. Let ${ }^{\wedge} \mathrm{tA}$ and $\wedge^{\wedge} \mathrm{tB}$ be the new marginal shareholder for country $A$ and $B$ respectively then we must have $\hat{t}_{A}<\hat{\mathrm{t}}_{B}$. Thus relative to $A$, there must be $\hat{t}_{B}<\hat{t}_{A}$ more new shareholders in $B$. However, when the two countries become integrated then B's banks will sell its new stock to the consumer that values it most highly irrespective of which country they belong to. Since equity valuation is inversely proportional to the probability of suffering a liquidity shock it pays for B's banks to issue some of its new stock to 
consumers in A who have $\hat{t}_{A}<t<\hat{t}_{B}$ and will therefore value B's shares more highly. Consequently, B's banks should sell exactly half of the excess capital required over an above the amount raised by A's banks to A's consumers and raise the rest domestically. That is, B's banks should sell $\hat{\mathfrak{t}}_{B}<\hat{t}_{2}^{A}$ shares to A's consumers and raise the rest domestically. It follows that the new marginal shareholder for B's banks post integration will be $\hat{t}_{B}<\hat{t}_{B}<\hat{t}_{2}^{A}=\hat{t}_{B}+\hat{t}_{A}<\hat{t}_{B}$.

Proof. (Lemma 3) The expected value of equity an the end of $\mathrm{T}=1, \mathrm{~EB} 1$, and the standard deviation across realizations, _B, are determined by equations (4) and (5) respectively. From equations (4) and (5), the only endogenous factor that will change the expected return or risk of the firm is the new level of deposits that they hold at $\mathrm{T}=1, \mathrm{D}_{1}$, all other variables are assumed exogenous. From previous discussion we have that $D_{B 1}=D_{0}<K_{1}^{B}$, so the only factor determining $\mathrm{D}_{B} 1$ is $K_{1}^{B}$. Prior to integration $K_{1}^{B}=\hat{t}_{B} d t$, post integration $K_{1}^{B}=t_{B} d t+\widetilde{t}_{B} \widetilde{t}_{B} d t A$, but $\tilde{t}_{B}=\hat{t}_{A}+\hat{t}_{2}^{B}$ so substituting this in gives us $K_{1}^{B}=\quad$ which is the same as the pre-integration level.

To see the reduction in the volume of strategic trades we restate equation (12) for a single economy here

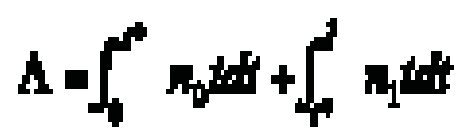

However, when the two countries are integrated and there is spillover of depositors from $\mathrm{A}$ to $\mathrm{B}$ then

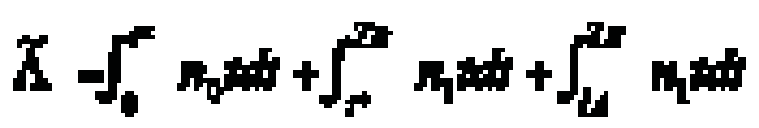

(All)

\section{Suppose that $\bar{A} \geq \Lambda$ then we num have}

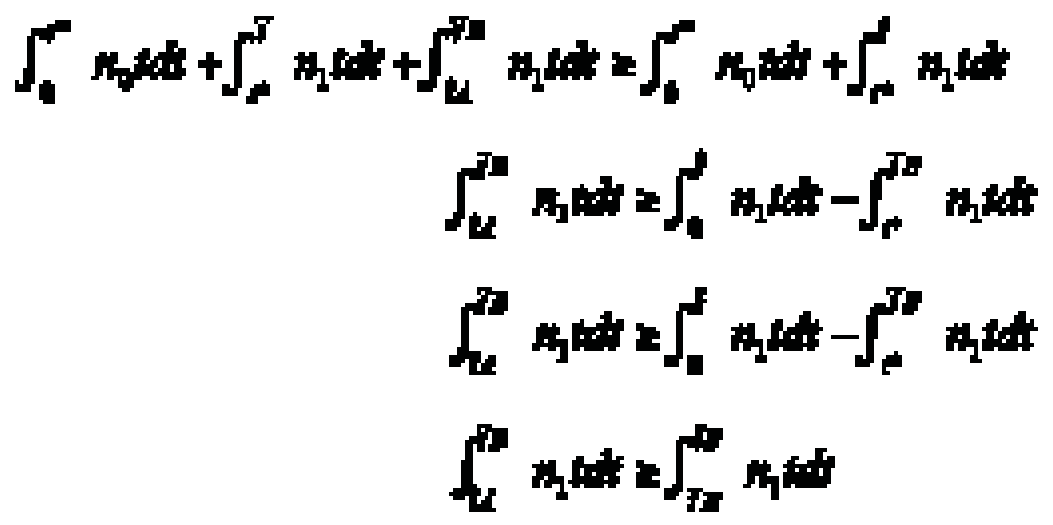


However, since $\mathrm{n} 1 \mathrm{t}$ is a linear monotonic increasing function and with $\hat{\boldsymbol{t}}_{\mathbf{A}} \boldsymbol{t}_{\mathbf{3}} \mathbf{(} \mathbf{3}$, this cannot be true, thus by contradiction the reverse statement must be true, that is $\tilde{\mathbf{n}}(\mathbf{A}$. This reduction in the volume of liquidity traders will, ceteris paribus, reduce the incentive for new shareholders to gather information as given by equation (10). Of course this leads to a reduction in the number of strategic traders. However, one would logically expect that the fall in volume of strategic traders to be smaller than the fall in the volume of liquidity traders.

This is because we originally assumed that there was a unique shareholder for which the information gathering condition - equation (10) - held with equality. That is, the new marginal informed shareholder lay somewhere between the old marginal shareholder and the new marginal shareholder. Thus, it would be logical to expect that post integration the marginal shareholder would once again locate somewhere between the new marginal shareholder and the old marginal shareholder which determines the number of strategic traders. Accordingly, the $\mathrm{T}$ $=2$ discount on country B.s bank equity will be higher.

Proof. (Proposition 2) If $\boldsymbol{\theta}_{\boldsymbol{A}} \boldsymbol{\theta}_{\boldsymbol{s}}$ then by lemma $1 \mathbf{1} \boldsymbol{\Sigma}_{1}^{\mathbf{A}}\left\langle\boldsymbol{\Sigma}_{\boldsymbol{1}}^{\boldsymbol{t}}\right.$. Consider once again the case where the two countries are segmented. Let $\boldsymbol{s}_{\mathbf{\Delta}}$ and $\hat{\mathbf{f}}_{\mathbf{f}}$ be the new marginal shareholder for country A and B respectively then $\boldsymbol{t}_{\boldsymbol{\Lambda}}(\boldsymbol{i}$, Proposition 1 tells us that the mark up on the cost of capital for new equity issuance at $\mathrm{T}=1$ is RD 1_^t_per dollar of deposit. Therefore, the cost of capital mark up per dollar of deposit for $A$ is less than that of B.s, that is, $R_{D !} d \hat{t}_{A} d A<R_{D 1} d \hat{t}_{B} d B$. Now if the countries become integrated then lemma 2 tells us that post integration $\mathrm{dt}_{\mathrm{B}}<0$, that is, the probability of the marginal shareholder in country $\mathrm{B}$ experiencing a liquidity shock decreases. While lemma 3 suggests that post integration $\mathrm{dB}>0$, that is, the $\mathrm{T}=2$ discount (due to the existence of strategic traders) on B.s equity traded in the secondary market increases. Assuming that $t_{B}>d B$ it follows that, post integration, $R_{D 1} d \widetilde{t}_{B} d B<R_{D 1} \hat{t}_{B} d B$. In other words, the cost of capital mark up per dollar of deposit is lower when the two countries are integrated with $\theta_{A}>\theta_{B}$. Moreover, the larger_A is, ceteris paribus, the greater the spillover of depositors and thus the greater the decline in B.s new marginal shareholders liquidity risk (lemma 2 ) and consequently an even larger reduction in the cost of capital mark up.

Proof. (Proposition 3) Consider the regulator's unconstrained design problem given by (16). Regulator B chooses a level of capture _B which in turn determines the level of capital raised $\mathrm{KB}_{1}$ in order to maximize their welfare function $W_{B P}$ given that regulator $A$ has chosen its level of capture optimally $\theta_{A}$. The first order condition yields 


$$
\frac{\partial W_{\theta}^{B}}{\partial \theta_{B}}=W P_{P}^{B}+\theta_{B} \frac{\partial W_{P}^{B}}{\partial \theta_{B}}-W_{S}^{B}+\left(1-\theta_{B}\right) \frac{\partial W_{S}^{B}}{\partial \theta_{B}}=0
$$

Taking the derivative of the first order condition w.r.t. $\theta$ A gives the following strategic interaction condition

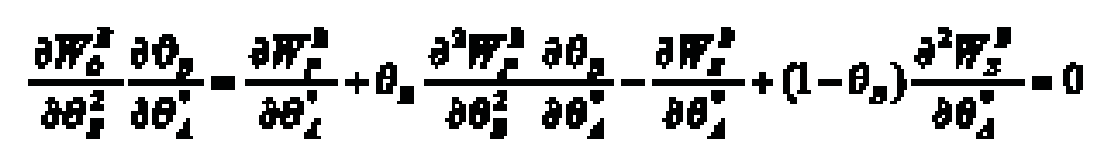

Solving fior $\frac{\partial \theta_{n}}{\partial \theta_{4}} w a$ h:ort

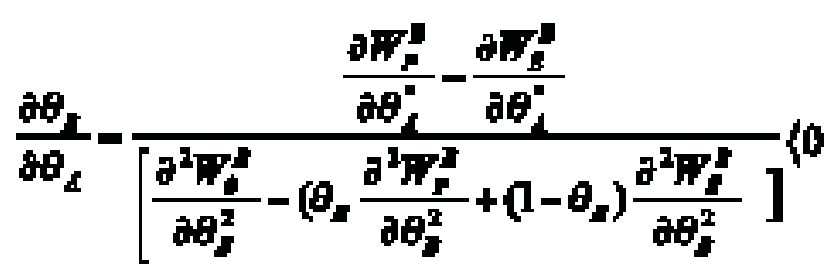

First, most of the welfare gains post integration accrue to the old shareholders of the banks in country B, they receive a reduction in the aggregate discount on new equity while the only benefit to social welfare is a reduction in aggregate

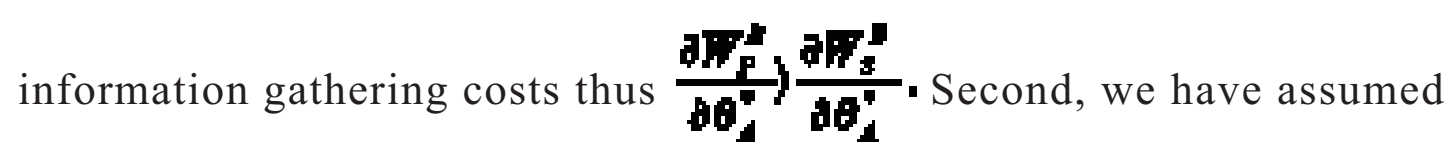
concavity of welfare functions so that $\frac{\partial^{2} W_{I}^{N}}{\Delta \theta_{I}^{2}}\left(0, \frac{\partial^{2} F_{I}^{S}}{\partial \theta_{I}^{2}}<0\right.$ and $\frac{\partial^{2} W_{I}^{N}}{\partial \theta_{I}^{2}}(0$. Note

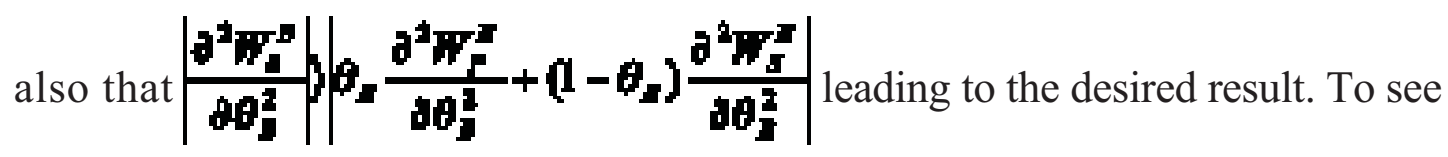
this consider once again the first order condition given by (A13). Differentiating this w.r.t. $\boldsymbol{\theta}_{\text {, }}$ again gives

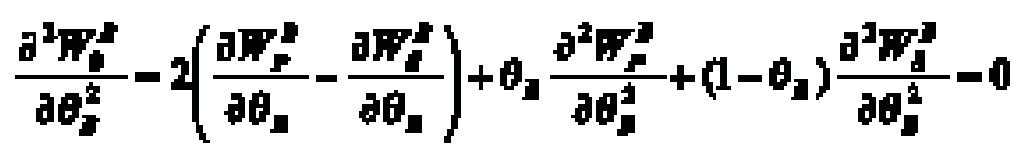

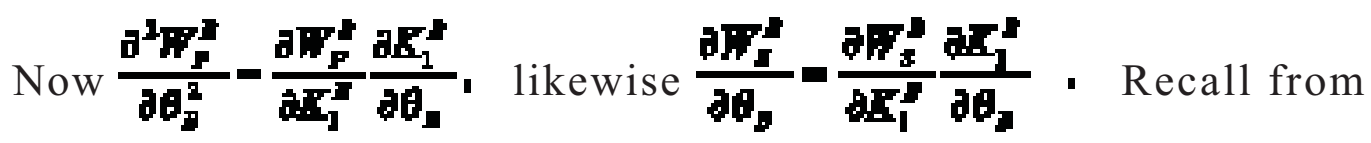

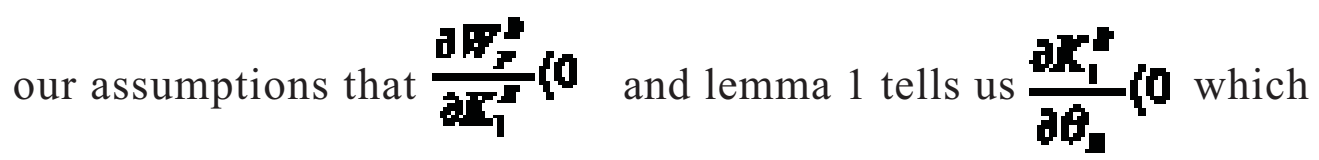

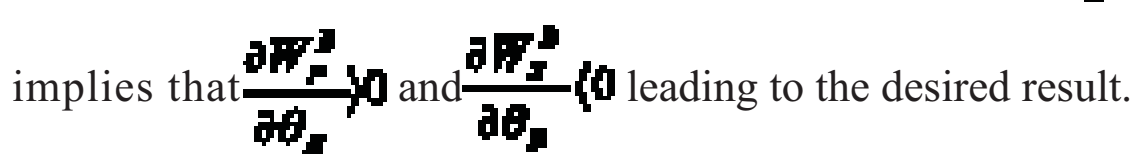

